\title{
Will Peace Flourish in the End? The History of Suffering: Terrorism in Turkey
}

\author{
Banu Baybars Hawks, Ph.D. \\ Kadir Has University, Faculty of Communications \\ Department of Public Relations and Information, Istanbul-Turkey \\ +90 2125336532 (1503), banubhawks@khas.edu.tr
}

\section{Doi:10.5901/mjss.2013.v4n10p278}

\begin{abstract}
For the past 30 years, the PKK has launched a campaign of terror in Turkey. Despite the rise and fall of attacks throughout the years, the PKK's terrorist activities have never completely ended. Through the recent initiative of the Turkish government, negotiations focusing on pacification have been launched with the leader of the PKK, Abdullah Öcalan, who is still in prison on Imrali Island. We have yet to see the outcome of this process. Terrorism is not simply about killing people; it is about destroying the population's sense of well-being and trust in the government. In addition to the casualties and physical pain caused directly by an attack, the normal reaction to an unfamiliar and life-threatening event - fear, stress, worry, grief and confusion -also inflict suffering and social pain. In a world where information and communication play a key part, terrorists try to achieve the maximum possible media impact by the violent acts they commit. So when we define terrorism, we have to keep in mind that a three-way relationship exists between the main protagonists: terrorists want something from the government and work to achieve it through the agency of public opinion by seeking to terrorize the public at large in the most spectacular way possible. Public opinion in turn is influenced by the media which sometimes produces exaggerated accounts of terrorist events. This paper will seek to examine how this three way relationship has developed during the negotiation process with the PKK in Turkey. It will investigate how the ruling government (AKP) initiated the process, how public opinion has been formed in such an environment and whether it has influenced the government's policies and decisions in regard to this issue. It will also explore how the media has reacted during this process. It is the author's hope that the findings will be useful for policy-makers, media scholars, and academicians, as well as lay readers interested in the topic.
\end{abstract}

Keywords: Terrorism, peace, Turkey, PKK, government, public opinion, media.

\section{Introduction}

For many years in much of the world, terrorism has been a major continuing threat to peace, freedom and progress. Terrorism continues today as the ultimate violation of human rights, through the carrying out of indiscriminate killings. Without the right to live, there are no rights at all.

Terrorism has been defined as "the unlawful use or threatened use of force or violence by a person or an organized group against people or property with the intention of intimidating or coercing societies or governments, often for ideological or political reasons" ("Terrorism," n.d.). The victims are anonymous, and the aim is to cause damage or spread a credible threat. To call an act as terrorism, an average "man on the street" needs to feel uneasy about his security (Leitzinger, 2002).

Terrorism has a long history, and numerous incidents of terrorism have occurred around the world throughout the centuries. Modern terrorism, however, dates back to the mid-19th century. Just as the Jacobins of the French Revolution held a "Reign of Terror" in 1794, communists and fascists shared a tendency to use terrorism. After World War II, terrorism became known on an international scale, but it can be argued that terrorism today knows no international boundaries. This new terrorism is less centralized, less structured, and less organized, but far more dangerous than the terrorism of the past.

Public opinion today is that one of the greatest threats to the peaceful and safe existence of humankind is generated by international terrorist organizations. The ever-increasing roles and power of non-state actors today have reached a point that they pose a challenge to the authority of nation-states. Turkey, with its long history of struggle against terrorism, is a prime example in this context.

Terrorism has been all too commonplace in Turkey since 1984 when the Kurdish Workers Party (PKK) began its armed struggle against Turkey. In Turkey, a country with a population of around 75 million people, nearly 40,000 lives have been lost in terrorism incidents over the past 29 years. 


\section{The History of the PKK Terrorism in Turkey}

The Kurdish Worker's Party (Partiya Karkeren Kurdistan, or PKK) is an ethnic separatist terrorist organization whose ideology is based on Marxist-Leninist principles. The organization's "use of terror and violence as a means of achieving its ultimate goal, the destruction of the territorial integrity of Turkey, is recognized and classified as an international terrorist organization by most western countries"( "A Case Study of the PKK in Turkey," n.d.).

The PKK was founded in 1974. The organization emerged from the leftist student groups active in Turkey in the 1960s. Abdullah Öcalan, a Kurdish student at Ankara University, joined the Revolutionary Youth Federation (Dev-Genç), an umbrella organization for such groups that was formed in 1970. The PKK's initial goal was to accomplish communist revolution in Turkey, a commonly observed phenomenon of leftist groups throughout the seventies. But Öcalan quickly changed his priorities from a broader-based leftist revolution to the "liberation" of the Kurds (Terrorism Project, n.d.). By 1974, the PKK had begun taking shape and, on Nov. 27, 1978, the organization had been secretly but formally set up in the district of Diyarbakir. The PKK confined itself to attacks on tribal chiefs in Urfa province until 1980. The same year the organization's leadership moved into the Syrian-controlled Bekaa valley in Lebanon. "By 1982 the group had secured initial financial backing from the Kurdish population in Libya, political backing from Libya, and training camps in Lebanon and Syria, and was geared towards expanding its activities significantly" (Ibid.). Starting in 1984, the organization intensified its acts of violence against Turkish targets with the aim of establishing a Kurdish state. The main targets in that period were "temporary village guards" - a paramilitary force set up by Turkey to combat the PKK - and other Turkish security forces. PKK attacked Turkish diplomatic and commercial premises across Europe in 1993 and again in 1995 (Ibid.). The group also employed suicide-bombing methods, waged mainly by female terrorists in Turkey, and kidnapped foreign tourists in the early to mid-1990s. In order to inflict damage on Turkey's economy, the organization also set forests in Turkey's tourist resorts on fire ("PKK and Terrorism," 2007). Öcalan was captured by the Turkish authorities in Kenya in early 1999, and the Turkish State Security Court subsequently sentenced him to death, a sentence later commuted to life imprisonment following the abolition of the death penalty ("A Case Study of the PKK in Turkey"). Following the capture of Öcalan in 1999, the PKK declared a cease-fire and began claiming that it had switched its strategy to peaceful methods and would pursue political struggle from then on. In April 2002, the organization changed its name to the Kurdish Freedom and Democracy Congress (KADEK), "alleging that PKK has fulfilled its historical mission and would now like to be accepted as a political organization" ("PKK and Terrorism"). In late 2003, the group underwent another name change to KONGRA-GEL (Kurdistan People's Congress), but neither of these two name changes nor the so-called strategy change of 1999 did changed the organization's real aims. The group still continued to carry out attacks mainly in southeastern Turkey, though not to the scale of the pre-1999 period (Ibid.). In August 2003, the government passed an amnesty law which encouraged the organization's members to leave the PKK. On May 29, 2004, the organization renounced its so-called unilateral cease-fire of the past five years. In 2005, the original name of the organization, PKK, was restored. In 2006 alone, the PKK killed over 500 people. In October 2006, the KGK/PKK declared a unilateral cease-fire that slowed the intensity and pace of its attacks, but attacks continued in response to Turkish security forces significant counterinsurgency and counter-terrorism operations, especially in the southeast of Turkey. Later, the PKK moved into northern Iraq and almost 3,500 PKK members have established a safe haven in Qandil. Since summer 2011, the conflict has become increasingly violent.

The PKK has also launched significant criminal activities inside Europe, ranging from extortion and trafficking drugs to smuggling illegal immigrants into European Union countries. The group also generates revenue by running media outlets (dailies, periodicals, and TV and radio channels) to help carry out anti-Turkey propaganda activities in many parts of the world ("PKK and Terrorism"). The economic cost of the conflict to Turkish government is estimated to be between 300 and 500 billion dollars.

\section{The Solution Process}

Since being formally declared a candidate for European Union (EU) membership in 1999, Turkey has deliberately set about expanding freedoms. When it announced Turkey as a candidate for membership, the European Union stipulated the steps necessary for Turkey to become a full member, including the rule of law, freedom of expression, human rights, constitutional reform and respect for the rights and protection of minorities ("The 1999 Regular Report from the European Commission on Turkey's Progress towards Accession," 13 October 1999). In accordance with EU membership requirements, Turkey has adopted a set of political and economic goals and tasks. Accordingly, 28 items in the 1982 Constitution of Turkey, which include restraints on freedom of thought and expression, the freedom and security of the 
individual, the privacy of individual life, the freedom of communication, the freedom of residence and movement, and freedom of association, underwent profound revisions in late 2001. Broadcasting in the Kurdish language, which heretofore had been illegal, was permitted under the new Turkish Constitution of 2001. The death penalty, which had not been meted out since 1984, could henceforth only be used in cases of acts of terrorism and treason with the new amendments, and despite this, Öcalan's life was spared despite overwhelming public demand for his execution. The use of Kurdish has been allowed in print media and the national public TV station TRT 6 since January 2004, and in March 2006, private television channels were allowed to begin airing programming in the Kurdish language. Since the summer of 2012, the government has accelerated democratic developments even more by "the approval of the municipality law; the adoption of the third judicial reform package; the approval of a law to allow legal defense in the Kurdish mother tongue in court; new regulations for conjugal visits - including for Öcalan; preparations for a fourth judiciary reform package; and meetings of government officials and members of the pro-Kurdish Peace and Democracy Party (BDP) with Öcalan" (Özcan, 2013). Constitutional changes, reform packages and law amendments have played a supporting role in the democratization process of the country and created an opportunity that had not foreseen in previous years as the AKP government to initiated peace talks with the PKK. In public discourse, the negotiations were referred to as a "solution process" (Çözüm Süreci).

In late 2012, the Turkish government began secret talks with Öcalan for a ceasefire, something that previously would have been unacceptable and unthinkable. After months of negotiations with the government, Abdullah Öcalan wrote a letter which was read both in Turkish and Kurdish during the Nowruz celebrations on the 21st of March, 2013 in Diyarbakır. The letter called for a cease-fire and the PKK stated that they would follow the order. On 25 April, the PKK announced that it would withdraw all of its forces from Turkey to and move them to northern Iraq (The Wall Street Journal, 25 April 2013).

\section{The Committee of Wise Men}

Realizing that it would be a challenge to change public opinion on the issue of the PKK, the government set up a consultative body on April 4, 2013 which was called the "committee of wise people," and this was composed of intellectuals, writers, academics, singers, and other well-known public figures. The members of the commission have been assigned to seven regions representing the country and entrusted with explaining the ongoing peace process to the public and promoting negotiations. "In a speech on March 23, the prime minister defined the role of the commission, saying they will be conducting a 'psychological operation,' indicating that the "wise people" will act as public relations agents" ("Solution Process," n.d.).

The opposition parties in Parliament, mainly the Republican People's Party (CHP) and the Nationalist Movement Party (MHP), stated that they would not take part in the commission claiming that the members of the body all government supporters. The commission gave its first report in May of 2013 regarding the level of support from the public for the negotiations.

\section{Public opinion}

According to a survey carried out in December 2012 by Kadir Has University, the Turkey Research Center, for which I am a coordinator, almost half of the population reported that they thought a military solution was the most effective approach for dealing with terrorism rather than political methods. In contrast to the previous year, the percentage of people who supported a military solution to the problem of terror increased to $50.1 \%$. To put it another way, one out of every two people thought that the solution to the problem of terror would best be carried out by the military. Due to the fact that peace talks have become a prominent issue for the government in recent days, this finding would surely interest the authorities as regards popular public opinion on the matter.

Likewise, the number of people who thought that negotiations should not be used to solve the problem of terrorism rose to 55.5\%. Taking into account regional differences, it was found that the percentage of people who supported negotiations with the Peace and Democracy Party (BDP) and Abdullah Öcalan was highest in southeastern and eastern Anatolia, where the population of Kurdish citizens is higher than in other regions. Eastern Anatolia was found to have the highest number of respondents who thought that negotiations with the Kurdish Workers Party (PKK) would be the best approach. Compared to the previous year, $20.5 \%$ more people thought that Abdullah Öcalan represented an effective aspect of solving the country's terrorism problems. Notably, $48 \%$ of respondents stated that they thought the government's policy vis-à-vis terrorism was unsuccessful. 
Nearly half of the interviewees claimed that the territorial integrity of Turkey was under threat (46.9\%), but it should be noted that the majority of people holding to this belief self-defined themselves as Socialist and Republican. It should also be noted that in terms of ethnic background, nearly half of the respondents who indicated they were Turkish said that they thought the territorial integrity of Turkey was in danger, and 4 out of 10 respondents who said they were Kurdish also felt that Turkey could be divided.

According to the survey findings, there was a decrease in the percentage of people who thought that the government was successfully handling the Kurdish issue. In the previous year, $39.7 \%$ of respondents stated that they thought the government was handling the problem unsuccessfully, and this figure increased to $50.5 \%$ in 2012 . Higher levels of education were also directly related to dissatisfaction with the government's handling of the Kurdish issue.

From 2011 to 2012, there was a decrease in the number of respondents who thought that the BDP and PKK represent the Kurdish people. Also, support for the idea that the BDP is able to effectively represent the Kurds in Turkey was at the lowest point of the last 3 years. However, when the respondents were Kurdish, this percentage was found to increase to 58.7\%, but the same did not hold true as regards the PKK; 1 out of 2 Kurdish citizens in Turkey stated that the PKK does not represent the Kurdish segment of the population. Just as in 2011, more than half of the participants indicated that the BDP cannot follow a policy that differs from the PKK, and the percentage of people who believe that the BDP and PKK are linked was 87\%. Similarly, 4 out of 5 respondents stated that they thought Abdullah Öcalan has an influence on the BDP and PKK. When asked what kind of government Kurdish people would like to have in the future, $68.9 \%$ of respondents said that the Kurds would like to have an autonomous Kurdish government.

In contrast to the findings of this research, a survey carried out by the ruling party (AKP) in May of 2013 suggested that $70 \%$ of people support the solution process.

\section{Conclusion}

Turkey's Kurdish issue is a fragile topic that has been intertwined with the terrorist activities of the PKK for almost 30 years. The PKK has intelligently used an argument which claims that "Kurds are unable to enjoy their political rights" to ensure the organization's long-term survival (Ozcan, 2013). Now, seeking to end this conflict which has been ongoing for three decades, the government has been trying to negotiate with the PKK. It appears that the process is progressing slowly but it is clear that many dynamics have been set in place to have an influence on this process.

For the Turkish public, it will be very challenging to change the negative public opinion on this issue because it is very hard and perhaps not possible to forget the years and years of pain and sorrow that are deeply rooted in history. At this stage, neither powerful opinion leaders (including government officials) nor the media have been able to successfully impact public opinion in regard to certain aspects of the Kurdish issue.

As regards the government, elections are upcoming and the AKP government would like to increase their voting potential in the 2014 regional and presidential and 2015 parliamentary elections to see if attempts at peace (if successful) are a good means to win more votes from both the Turkish and Kurdish segments of the population. On the other hand, they are aware that if the process is not handled correctly, they may lose some of their own voters and this could create an advantage for the opposition parties that have voiced nationalist sentiment. In order to prevent this, the government established the "committee of wise men" and has tried to convince the public of the necessity of negotiations.

From the Kurdish perspective, different dynamics are at work as well. The first is about the structure of the organization. Even though Abdullah Öcalan is supposedly the first most powerful figure in the PKK, the organization is not a one-man-show, and there are many unknown elements within it. In addition, there are some countries that the PKK has developed relations with over the years. It is probable that those countries would not want to see the organization out of the picture because they have mutual interests. This represents an obstacle to the peace settlement process. Also, since one arm of the PKK which is responsible for financing the organization is involved in criminal activities including human and drug trafficking, it won't be difficult to predict that they will try to disrupt the process (Ozcan, 2013).

As the findings of the public opinion surveys indicate, the majority of Kurdish citizens in Turkey believes that the PKK does not represent the Kurdish segment of the population. This indicates the importance of finding an alternative for the PKK to discuss the rights and interests of the Kurds. The Peace and Democracy Party (BDP) is not seen as an alternative because more than half of the survey participants indicated that the BDP cannot follow a policy that differs from the PKK, and the percentage of people who believe that the BDP and PKK are linked was 87\%. If the BDP would like to increase its support from the public on this issue, they should separate themselves from the PKK and produce alternative policies. 
If successful, the ongoing peace settlement negotiations with the PKK will produce important benefits for Turkey socially, politically, and economically. Turkey needs to keep the process on track against all the odds. If the attempts prove to be successful, Turkey could become a leader and role model for other countries in terms of conflict resolution.

\section{References}

Albayrak, A., \& Parkinson, J. (2013, April 25). Kurdish Group to Pull Armed Units from Turkey. The Wall Street Journal. Retrieved from http://online.ws..com/article/SB10001424127887324743704578444630691252760.html

Foundation for Middle East and Balkan Studies. (n.d). A Case Study of the PKK in Turkey. Retrieved from http://www.fas.org/irp/ world/para/docs/mfa-t-pkk2.htm.

Leitzinger, A. (March 2002). The Roots of Islamic Terrorism. Retrieved from http://www.cc.jyu.fi/ aphamala/pe/issue5/roots.htm.

Özcan, M. (2013, March 4). Seeking new solution paths for the Kurdish issue. European Policy Centre. Retrieved from http://www.epc.eu/pub_details.php?cat_id=4\&pub_id=3350.

PKK and Terrorism. 23 October 2007. Retrieved from http://www.turkishpress.com/news.asp?id=199467.

Solution Process. (n.d.). Retrieved from http://en.wikipedia.org/wiki/Solution_process.

Terrorism. (n.d.). Retrieved from http://www.dictionary.com.

Terrorism Project. (n.d.). In the Spotlight: PKK (A.k.a KADEK) Kurdish Worker's Party (A.k.a. Kurdish Freedom and Democracy Congress)'. Retrieved from http://www.cdi.org/terrorism/pkk-pr.cfm.

The 1999 Regular Report from the European Commission on Turkey's Progress towards Accession. 13 October 1999. Retrieved from http://europa.eu.int/comm/enlargement/report_10_99/pdf/en/turkey_en.pdf, p.10. 